\title{
Producing Safe Drinking Water Using an Atmospheric Water Generator (AWG) in an Urban Environment
}

\author{
Offir Inbar ${ }^{1}$, Igal Gozlan ${ }^{1}$, Stanislav Ratner ${ }^{2}$, Yaron Aviv ${ }^{1,2}{ }^{\mathbb{D}}$, Roman Sirota ${ }^{2}$ \\ and Dror Avisar $1, * \mathbb{D}$ \\ 1 The Water Research Center, Porter School for Environment and Earth Sciences, Faculty of Exact Sciences, \\ Tel Aviv University, Tel Aviv 66978, Israel; offirinbar@gmail.com (O.I.); gozlan.igal@gmail.com (I.G.) \\ 2 Watergen LTD, 2 Granit St, Petach Tikva 4951446, Israel; ratners@watergen.com (S.R.); \\ yarona@watergen.com (Y.A.); romans@watergen.com (R.S.) \\ * Correspondence: droravi@tauex.tau.ac.il
}

Received: 22 September 2020; Accepted: 17 October 2020; Published: 21 October 2020

\begin{abstract}
Alternative new technologies are urgently needed to overcome the rapidly increasing global water scarcity. Atmospheric dew water is a potential source of potable water, as the earth's atmosphere contains billions of tons of fresh water ( $98 \%$ in a vapor state). The atmospheric water generator (AWG) converts water vapor into liquid water and is a promising solution for water scarcity. We provide the first comprehensive analysis of the chemical profiles of water produced for several months by an AWG in the city of Tel Aviv, Israel. Metals, inorganic ions, volatile organic compounds (VOCs), and semi-VOCs were analyzed in the dew water. The main elements found were ammonium, calcium, sulfate, and nitrate. Location of the sampling site in an urban residential area, between major traffic routes, likely affected the chemical composition of the produced dew water. Nevertheless, the produced water nearly always (day and night in different seasons) met the WHO and Israeli drinking water standards. Thus, even in a highly developed urban environment, the AWG offers an excellent alternative source of safe drinking water throughout the year.
\end{abstract}

Keywords: atmospheric water generator; water quality; drinking water; alternative water resource; atmospheric water chemistry

\section{Introduction}

\subsection{Global Water Scarcity and Alternative Drinking Water Sources}

Freshwater scarcity is an ever-growing concern for human society [1]. In its last report, the World Economic Forum listed water crises as one of the top five global risks to Man worldwide, in terms of impact and likelihood [2]. Currently, over 2 billion people across the globe are experience high water scarcity, a number that is expected to rise with population growth and the intensity of climate change [3].

Solutions for water scarcity are based on various water-saving strategies, reclaiming of used water, and water production. Seawater desalination by reverse osmosis is the most common and efficient water-production method [4]. However, it requires a large saline or brackish water source and is therefore not applicable in regions with no access to brackish or sea water. Moreover, desalination plants and long pipelines require large capital investments. Distillation is therefore not relevant to poor and noncoastal regions, many of which suffer from chronic severe water scarcity. Production of atmospheric water is another potential source of potable water. The earth's atmosphere is a huge and renewable water resource, containing approximately 12,900 billion tons of fresh water [5]—98\% vapor and the rest in a condensed state (clouds and fog). 


\subsection{Atmospheric Water}

Dew water consists of the water droplets formed when atmospheric water vapor condenses on surfaces with temperatures below the dewpoint temperature. The main advantage of using atmospheric water as a drinking water source is that there is no need to build a water-transport infrastructure; harvesting apparatuses can be placed almost anywhere (away from the coastline). There are two main types of dew condensers-passive and active. The active condensers are also known as atmospheric water generators (AWGs). The passive condensers rely on exploiting the physical processes responsible for dew formation to collect dew water without any additional energy input [6,7]. However, due to the very specific weather conditions necessary for maximum condensation of dew (i.e., relative humidity $\sim 80 \%$, cloud cover, and low but greater than zero wind speed), the water yield per day is relatively low and difficult to predict. In practice, $1 \mathrm{~m}^{2}$ of passive condenser can yield $0.3-0.6 \mathrm{~L} /$ day $[6,8]$; this is not sufficient for a reliable water source.

The AWG converts water vapor into liquid water, mostly by condensation. It cools the moist air to temperatures below its dew point, causing a phase change from vapor to liquid water over the cooling surfaces, which is then collected [7,9]. Condensation-based AWGs operate on a vapor-compression refrigeration cycle (Section 2.2). The most promising advantage of the AWG is its ability to produce water from relatively dry air and low temperatures. Although relative humidity is a significant factor in the AWG's efficiency, it is less affected by variable abiotic conditions such as sky emissivity, wind speed, and topographic location than passive condensers. Therefore, it can potentially be operated under a wider range of weather conditions [10]. Moreover, the AWG can produce higher water yields than the passive method through additional energy inputs. AWGs can reach up to $5000 \mathrm{~L} /$ day of potable water [11]. Thus, the AWG is a promising option as an alternative or supplemental source of water in dry, inland, and poor water-scarce regions. Several AWG devices are commercially available [12-14]. These systems are especially suited to areas with high temperatures and humidity levels that increase the water yield due to the increased water content of the air. The water-generation efficiency varies significantly between brands and depends on the meteorological conditions. The estimated in-situ production ranges from $0.3 \mathrm{kWh} / \mathrm{to} 0.65 \mathrm{kWh} / \mathrm{L}$ [15]. AWGs may include air- and water-filtration systems and water-treatment technologies to reduce various types of chemical and biological contamination.

The chemical properties of dew water are characterized by the atmospheric aerosols that deposit on the dew-harvesting device, acting as nucleation sites for dew condensation and reacting with atmospheric gases that can be absorbed by the water [16]. It is not fully understood why the compositions and concentrations of dew water vary considerably in time and space [17]. It has been suggested that the dew's chemical properties largely reflect the local environment, while others have pointed out that pollutants are more efficiently transported under unstable anticyclone conditions, enabling dew to be an indicator of long-range transport phenomena [18-20]. In addition, the chemical characteristics of the dew water are significantly influenced by land profile and meteorological conditions, such as weather and atmospheric mixing layer height [21-23]. Several studies have analyzed the chemical characteristics of dew water. In most cases, the dew chemistry met the standards of both the Israeli (IL) and World Health Organization (WHO) drinking water guidelines. Generally, the main constituents in dew water are ammonium $\left(\mathrm{NH}_{4}{ }^{+}\right)$, calcium $\left(\mathrm{Ca}^{2+}\right)$, sulfate $\left(\mathrm{SO}_{4}{ }^{2-}\right)$, and nitrate $\left(\mathrm{NO}_{3}{ }^{-}\right)$[16]. Toxic metals may also be detected $[6,16]$.

The AWG is considered a promising option as an alternative or supplemental source of safe drinking water, the quality of which, as already noted, is dependent on air and meteorological parameters. As far as we know, all studies analyzing the profiles of harvested dew water have looked at water from passive dew condensers. In this study, we provide the first comprehensive chemical profile (metals, ions, ammonium, semi-volatile organic compounds (semi-VOCs), and VOCs) of atmospheric water harvested by an AWG. Our aim was to determine whether the atmospheric water produced by an AWG located in Tel Aviv can meet the WHO and IL drinking water standards. 


\section{Materials and Methods}

\subsection{Study Area}

The sampling station is located in northern Tel Aviv (Figure 1), near the campus of Tel Aviv University ( $32^{\circ} 07^{\prime} 09^{\prime \prime} \mathrm{N}$; $\left.34^{\circ} 48^{\prime} 17^{\prime \prime} \mathrm{E}\right), 39 \mathrm{~m}$ above sea level, $16 \mathrm{~m}$ above the ground. The station is located within the largest urban and industrial metropolitan area in Israel, $1 \mathrm{~km}$ from major roads and about $2 \mathrm{~km}$ from the Mediterranean coast. This site is adjacent to an air monitoring station operated by the Israeli Ministry of Environmental Protection that continuously monitors a wide range of meteorological and air parameters (data can be retrieved from: http://www.sviva.gov.il/English/env_ topics/AirQuality/Pages/NationalAirMonitoringNetwork.aspx). Water samples were collected from June 2019 to March 2020 under different climatic conditions, at different hours and over several seasons.

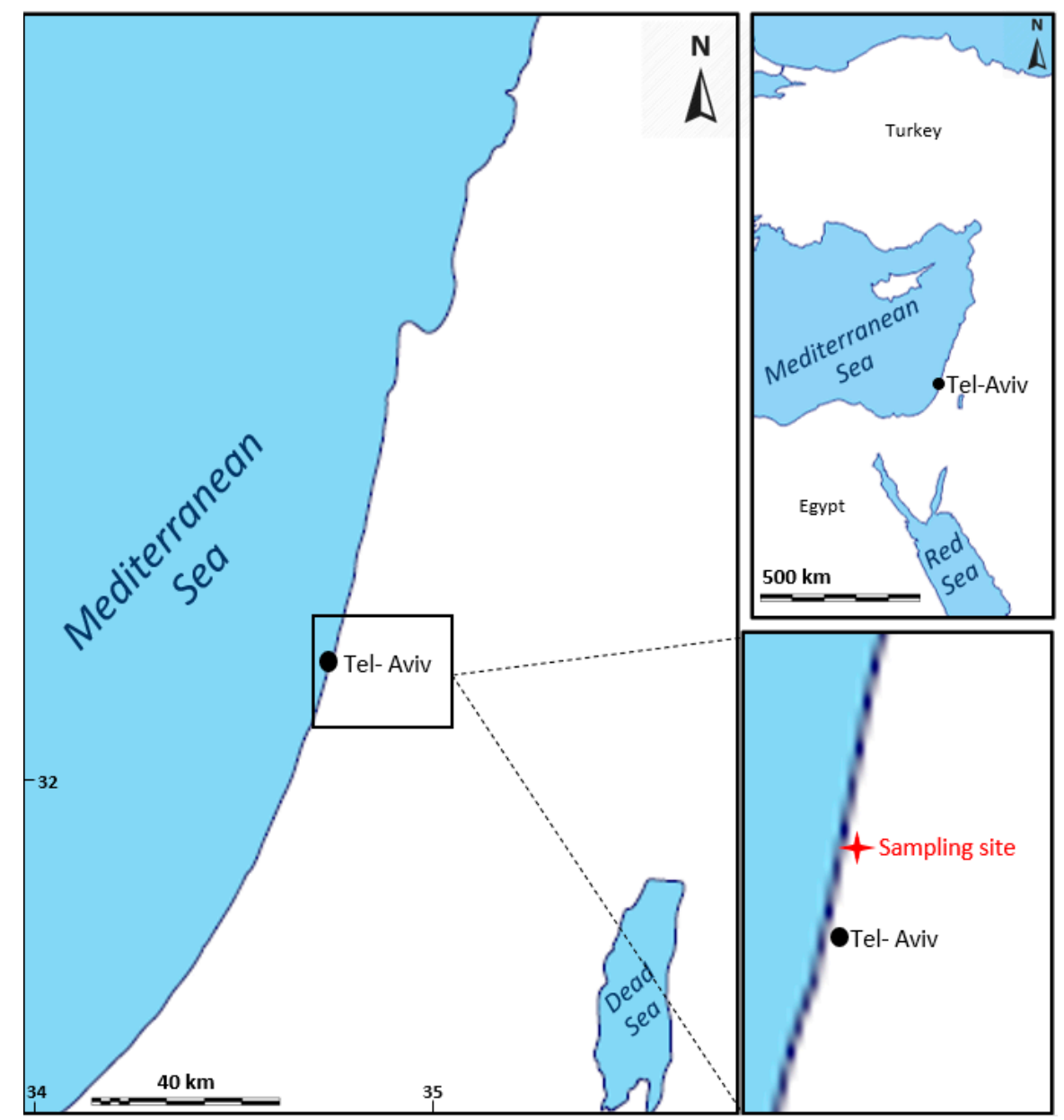

Figure 1. Sampling site location.

\subsection{AWG Apparatus}

The sampling station is located in northern Tel Aviv (Figure 1), near the campus of Tel Aviv University ( $\left.32^{\circ} 07^{\prime} 09^{\prime \prime} \mathrm{N} ; 34^{\circ} 48^{\prime} 17^{\prime \prime} \mathrm{E}\right), 39 \mathrm{~m}$ above sea level, $16 \mathrm{~m}$ above the ground. The station is located $1 \mathrm{~km}$ from major roads and about $2 \mathrm{~km}$ from the Mediterranean coast.

The unique AWG was designed and built by WaterGen Ltd., an Israeli-based company that is a leader in the manufacture of commercial systems to produce water from the atmosphere. The apparatus was designed to meet the specific research requirements (e.g., does not contain any post-treatment technology) and is not used for commercial purposes. 
The air-into-water (Figure 2) process takes place as the air enters the AWG at ambient temperature. When it meets the evaporator, condensation occurs, and water is collected into the water tank. More specifically, from the evaporator, the vapor passes through a compressor where it reaches high pressure and temperature and condenses into a liquid state in the condenser by emitting the heat back into the environment. The expansion process occurs at the expansion valve where the temperature and pressure of the vapor decrease. The vapor enters the evaporator where evaporation occurs naturally due to the reduction in pressure, and when ambient air contacts the vapor, the cycle starts again.

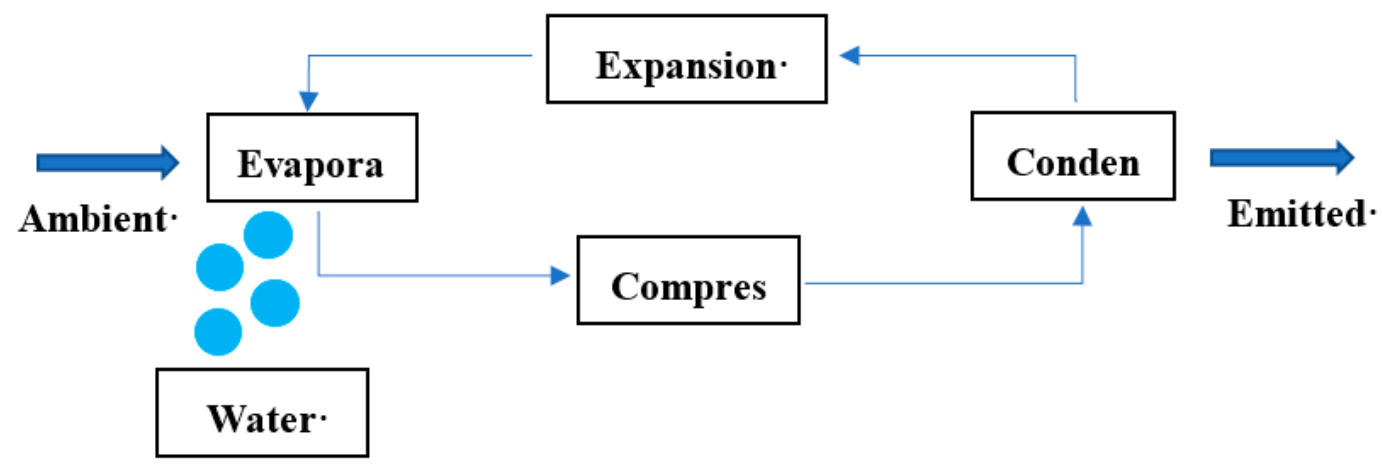

Figure 2. Air-into-water: The Atmospheric Water-Generator process.

The unique AWG (Figure 3) used in this research produces water at a minimum temperature of $10{ }^{\circ} \mathrm{C}$ and cools the ambient air to $8{ }^{\circ} \mathrm{C}$ below the dew point, with an average airflow of $400 \mathrm{~m}^{3} / \mathrm{h}$ and a compressor power of $1000 \mathrm{~W}$. It has two $2 \mathrm{~L}$ water tanks that are completely separate from each other and the apparatus can be programmed to produce water at a specific time for each container. The device is $35 \mathrm{~cm}$ high, $25 \mathrm{~cm}$ long, and $14 \mathrm{~cm}$ wide.

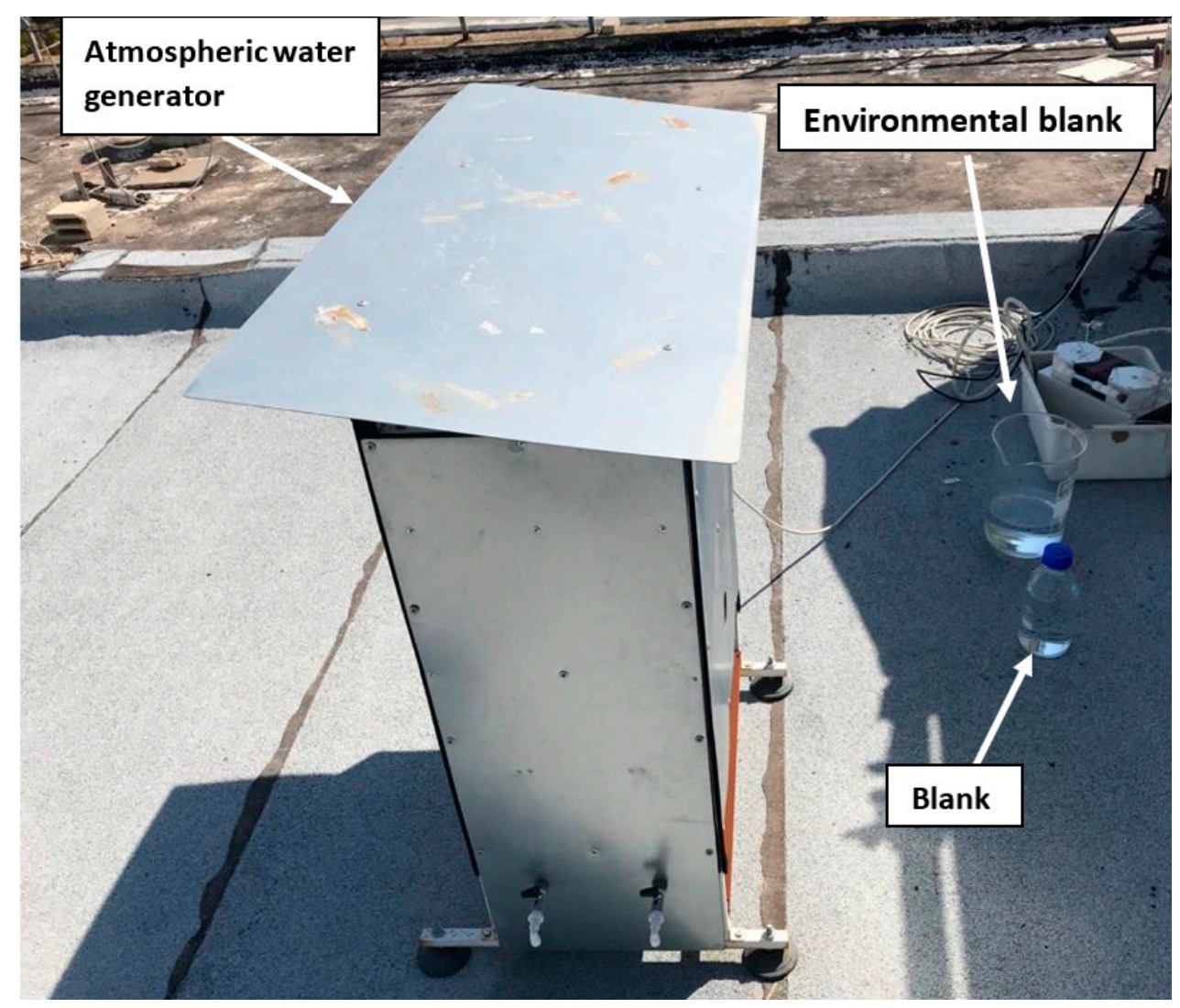

Figure 3. Experimental setup. Atmospheric water generator, blank, and environmental blank. 
The substances with which the air/water comes into contact from the moment the air enters the machine until it reaches the water tank are: (1) polyethylene terephthalate (PET), (2) aluminum 8016 which consists of silicon $(0.2 \%)$, iron $(1 \%)$, copper $(0.1 \%)$, magnesium $(0.1 \%)$, manganese $(0.2 \%)$, zinc $(0.1 \%)$, and others (each at $0.05 \%$ for a total of $0.15 \%)$; the rest is aluminum $(98.15 \%)$, (3) polyethylene (PE) tubes, (4) copper tubes, (5) polyoxymethylene (POM) connectors, (6) a water tank made from stainless steel type 316 , which consists of carbon $(\leq 0.08 \%)$, manganese $(2 \%)$, phosphorus $(0.045 \%)$, sulfur $(0.03 \%)$, silicon $(0.75 \%)$, chromium $(16 \%)$, nickel $(10 \%)$, molybdenum $(2 \%)$, and iron $(69.095 \%)$.

It should be reiterated that the unique AWG does not have any air/water-filtration systems or water-treatment technologies.

\subsection{Sampling Methods}

Water samples were taken directly from the AWG, at the highest possible level of sterility and caution, to avoid external contamination. The water from the AWG container was collected into clean $2 \mathrm{~L}$ glass bottles. The bottles were closed and shaken. Water was then immediately portioned into the various test tubes as needed. The test tubes were stored in a $4{ }^{\circ} \mathrm{C}$ refrigerator until analyses.

Each water sampling was accompanied by two types of blanks that were subjected to all of the same processes. The first blank contained $900 \mathrm{~mL}$ distilled water in a $1 \mathrm{~L}$ glass bottle that was closed with a stopper. Its purpose was to check that there is no contamination in the process (test tubes, vials, or refrigerator) and that there is no contamination in the instrument used to perform the analysis. The second (environmental) blank contained $900 \mathrm{~mL}$ distilled water in a $3 \mathrm{~L}$ open glass beaker with a diameter of $20 \mathrm{~cm}$. Its purpose was to investigate whether and how the environment affects the composition of the water, and to identify specific contaminants entering the water. The bottles were placed next to the apparatus throughout the experiment (Figure 3).

\subsection{Analytical Methods}

Metal composition was analyzed by inductively coupled plasma-optical emission spectrometry (ICP-OES; SPECTRO ARCOS series, Kleve, Germany), which was calibrated to detect and quantify a variety of metal elements in the range of several micrograms per liter to hundreds of milligrams per liter. The list of analyzed metals is given in Section 3.1.1. Sample preparation consisted of acidifying a 40-mL sample of water with $400 \mu \mathrm{L}$ nitric acid (65\%).

Major inorganic Ions were analyzed by ion chromatograph (IC; Integrion HPIC, Dionex Integrion, ThermoFisher Scientific, Waltham, MA, USA). The IC was calibrated to detect and quantify a variety of ions in the range of several micrograms per liter to several milligrams per liter. The IC column was a Dionex IonPac AERS 500, $4 \times 250 \mathrm{~mm}$, with a flow of $1 \mathrm{~mL} / \mathrm{min}$ and mobile phase composition of: 0-11 min $23 \mathrm{mM} \mathrm{KOH}, 11-16 \mathrm{~min} 50 \mathrm{mM} \mathrm{KOH}$, and 16-22 $\min 23 \mathrm{mM}(\mathrm{KOH})$. Ammonium was analyzed using the ion-selective electrode (ISE) method with a Two-Channel Benchtop pH/mV/ISE meter with a Hanna HI4101 electrode. The limit of quantification (LOQ) of ammonium was $100 \mu \mathrm{g} / \mathrm{L}$. Sample preparation consisted of placing $20 \mathrm{~mL}$ water produced by the machine in a tube and adding 1 drop of $32 \% \mathrm{HCl}$.

Two families of semi-volatile organic compounds (SVOCs), polychlorinated biphenyls (PCBs) and polycyclic aromatic hydrocarbons (PAHs), were analyzed by gas chromatography/mass spectroscopy (GC/MS). The GC/MS (model 6890/5973, Agilent, Santa Clara, CA, USA) was equipped with a liquid autosampler and an Rxi-5Sil MS column $(30 \mathrm{~m}, 250 \mu \mathrm{m}, 0.25 \mu \mathrm{m}$, Restek, Bellefonte, PA, USA). Running conditions were: oven temperature-initial $40^{\circ} \mathrm{C}$, hold for $1 \mathrm{~min}$ then raise to $280^{\circ} \mathrm{C}$ at $15{ }^{\circ} \mathrm{C} / \mathrm{min}$, hold for $1 \mathrm{~min}$ then raise to $320^{\circ} \mathrm{C}$ at $15{ }^{\circ} \mathrm{C} / \mathrm{min}$, hold for $5 \mathrm{~min}$; injection volume of $2 \mu \mathrm{L}$; injector temperature of $250^{\circ} \mathrm{C}$; injection mode-splitless with purge time of $0.75 \mathrm{~min}$; carrier gas-helium; transfer line of $280^{\circ} \mathrm{C}$.

The mass spectrometer was set to selected ion monitoring (SIM) mode for both PAHs and PCBs, along with an internal standard (IS) that was used to improve the accuracy and precision of the quantitative analysis. The list of analyzed SVOCs is given in Appendix A. The calculations were 
performed in accordance to a calibration curve with a concentration range of $0.2-500(\mu \mathrm{g} / \mathrm{L})$ for each analyte (PCB and PAH). The correlation (R2) for all compounds was not less than 0.995 . The sample was prepared by placing $100 \mathrm{~mL}$ water produced by the machine into a test tube and adding $5 \mathrm{~g} \mathrm{NaCl}$, $25 \mu \mathrm{L}$ IS with a concentration of $50 \mathrm{mg} / \mathrm{L}$, and $5 \mathrm{~mL}$ hexane; the tube was vigorously shaken manually. After phase separation, $1 \mathrm{~mL}$ from the top fraction (the organic phase) was placed into a GC vial.

Headspace (MPS 2XL autosampler, Gerstel, Linthicum, MD, USA) GC/MS technique was used to analyze VOCs. The GC/MS parameters were: 624Sil MS column $(60 \mathrm{~m}, 250 \mu \mathrm{m}, 1.4 \mu \mathrm{m}$, Restek, Bellefonte, PA, USA); oven temperature-initial $40{ }^{\circ} \mathrm{C}$, hold for $2 \mathrm{~min}$ then raise to $240{ }^{\circ} \mathrm{C}$ at $8{ }^{\circ} \mathrm{C} / \mathrm{min}$; injection volume of $1000 \mu \mathrm{L}$; injector temperature of $220^{\circ} \mathrm{C}$; injection mode-splitless with purge time of $0.05 \mathrm{~min}$; carrier gas-helium; transfer line of $280^{\circ} \mathrm{C}$. Headspace parameters were: incubation temperature of $80^{\circ} \mathrm{C}$, incubation time of $20 \mathrm{~min}$, syringe temperature of $90^{\circ} \mathrm{C}$, agitator speed of $500 \mathrm{rpm}$ and fill speed of $200 \mu \mathrm{L} / \mathrm{s} ; 10 \mathrm{~mL}$ of sample was taken for the analysis. The mass spectrometer was set to SIM mode, and the IS used in the VOC analysis was fluorobenzene. The list of analyzed VOCs is given in Appendix B. The calculations were performed in accordance to the calibration curve with a concentration range of $0.1-500(\mu \mathrm{g} / \mathrm{L})$ for each analyte. R2 for all compounds was not less than 0.995 .

$\mathrm{pH}$ was determined using a calibrated $\mathrm{pH}$ meter (MA235, Mettler Toledo, Columbus, OH, USA). $\mathrm{NH}_{4}{ }^{+}$was detected by a Hanna HI5222 selective electrode.

\section{Results and Discussion}

\subsection{Overall Dew Water Quality Meets Drinking Water Standards}

Dew water is the result of water vapor condensation. The dew collector (or substrate) and the atmosphere give the dew water unique chemical characteristics. We analyzed various chemicals in the dew water-metals, inorganic ions, $\mathrm{NH}_{4}{ }^{+}$, VOCs, and SVOCs. The results were compared to the drinking water guidelines of the $[24,25]$ standards. A total of 64 water samples were collected from June 2019 to March 2020 under different climatic conditions, at different hours of the day and over several seasons. None of the measured chemicals (except nickel and benzo[a]pyrene in rare occasional samples), exceeded drinking water standards, although the standard deviation (SD) between samples was significant due to the varied climatic conditions. The median value for both blanks was less than the LOQ for the metals, ions, and $\mathrm{NH}_{4}{ }^{+}$. We had some concerns about the active dew collector inside the AWG apparatus becoming contaminated. However, examination showed this not to be the case, as the values on subsequent days were not affected by each other (Appendix C). Moreover, some chemical elements that constituted a major part of the device, such as iron, chromium, molybdenum, and aluminum, were not found at all or only in very small quantities (less than $5 \mu \mathrm{g} / \mathrm{L}$ ) in the dew water.

\subsubsection{Metals}

Although a few of the examined metals are essential to human health, excess amounts of others can have severe negative health effects, and their quantity in the dew water must be monitored. A total of 24 metals were studied in this research (Table 1). The concentrations of the common metals zinc, aluminum, and copper were an order of magnitude lower than the drinking water standards (Figure 4). Zinc exceeded the LOQ 58 times $(n=64)$, with a median value of $11 \mu \mathrm{g} / \mathrm{L}$. The main source of zinc pollution is the abrasion of vehicle tires. However, previous studies have also shown the impact of several long-range transport processes on the characteristics of aerosol over Israel [26]. Thus, during the winter, zinc originated mostly from local (Israeli) sources (vehicles), whereas during the summer it was part of the long-range aerosol transport from southwestern Europe [27]. 
Table 1. Metals and Ions analyzed in the dew water.

\begin{tabular}{|c|c|c|c|c|c|}
\hline Description & $\begin{array}{c}\mathrm{LOQ} \\
(\mu \mathrm{g} / \mathrm{L})\end{array}$ & $\begin{array}{l}\text { Median } \\
(\mu \mathrm{g} / \mathrm{L})\end{array}$ & $\begin{array}{l}\text { Standard Deviation } \\
\text { (SD) }\end{array}$ & $\begin{array}{c}\text { WHO Guidelines } \\
(\mu \mathrm{g} / \mathrm{L})\end{array}$ & $\begin{array}{l}\text { Israeli Guidelines } \\
\qquad(\mu \mathrm{g} / \mathrm{L})\end{array}$ \\
\hline \multicolumn{6}{|l|}{ Metals } \\
\hline Silver (Ag) & 5 & $<$ LOQ & - & - & 100 \\
\hline Aluminum (Al) & 5 & 8 & 7.32 & - & 200 \\
\hline Arsenic (As) & 2 & $<\mathrm{LOQ}$ & - & 10 & 10 \\
\hline Barium (Ba) & 1 & 1.4 & 1.39 & 700 & 1000 \\
\hline Beryllium (Be) & 1 & $<\mathrm{LOQ}$ & - & - & 4 \\
\hline Calcium (Ca) & 20 & 176 & 446 & - & - \\
\hline Cobalt (Co) & 2 & $<\mathrm{LOQ}$ & - & - & - \\
\hline Cadmium (Cd) & 1 & $<$ LOQ & - & 3 & 5 \\
\hline Chromium (Cr) & 1 & $<$ LOQ & - & 50 & 50 \\
\hline Copper $(\mathrm{Cu})$ & 5 & 140.5 & 110.02 & 2000 & 1400 \\
\hline Iron $(\mathrm{Fe})$ & 5 & $<$ LOQ & 1.17 & 300 & 1000 \\
\hline Potassium (K) & 20 & $<\mathrm{LOQ}$ & 26.06 & - & - \\
\hline Nickel (Ni) & 5 & $<\mathrm{LOQ}$ & 101 & 70 & 20 \\
\hline Lead $(\mathrm{Pb})$ & 1 & $<\mathrm{LOQ}$ & 0.87 & 10 & 10 \\
\hline Antimony (Sb) & 2 & $<\mathrm{LOQ}$ & 3.65 & 20 & 6 \\
\hline Thallium (Tl) & 1 & $<\mathrm{LOQ}$ & - & - & 2 \\
\hline Vanadium (V) & 10 & $<\mathrm{LOQ}$ & - & - & - \\
\hline Selenium (Se) & 10 & $<\mathrm{LOQ}$ & - & 40 & 10 \\
\hline Zinc (Zn) & 2 & 10.7 & 28.88 & - & 5000 \\
\hline Mercury (Hg) & 1 & $<\mathrm{LOQ}$ & - & 6 & 1 \\
\hline Manganese (Mn) & 20 & $<\mathrm{LOQ}$ & - & - & 200 \\
\hline Molybdenum (Mo) & 2 & $<\mathrm{LOQ}$ & - & 70 & 70 \\
\hline Sodium (Na) & 20 & 69 & 344.37 & - & - \\
\hline Magnesium (Mg) & 20 & 35.5 & 50.6 & - & - \\
\hline \multicolumn{6}{|l|}{ Ions } \\
\hline Bromide $\left(\mathrm{Br}^{-}\right)$ & 100 & $<\mathrm{LOQ}$ & 17.5 & - & - \\
\hline Chloride $\left(\mathrm{Cl}^{-}\right)$ & 100 & 120 & 214.1 & - & 400,000 \\
\hline Fluoride $\left(\mathrm{F}^{-}\right)$ & 20 & $<$ LOQ & 15.8 & 1500 & 1700 \\
\hline Nitrate $\left(\mathrm{NO}_{3}{ }^{-}\right)$ & 100 & 180 & 286.1 & 50,000 & 70,000 \\
\hline Nitrite $\left(\mathrm{NO}_{2}{ }^{-}\right)$ & 100 & $<$ LOQ & 200.8 & 3000 & 3000 \\
\hline Phosphate $\left(\mathrm{PO}_{4}^{-}\right)$ & 200 & $<\mathrm{LOQ}$ & 218.4 & - & - \\
\hline Sulfate $\left(\mathrm{SO}_{4}^{-}\right)$ & 100 & 240 & 374.5 & - & 250,000 \\
\hline
\end{tabular}



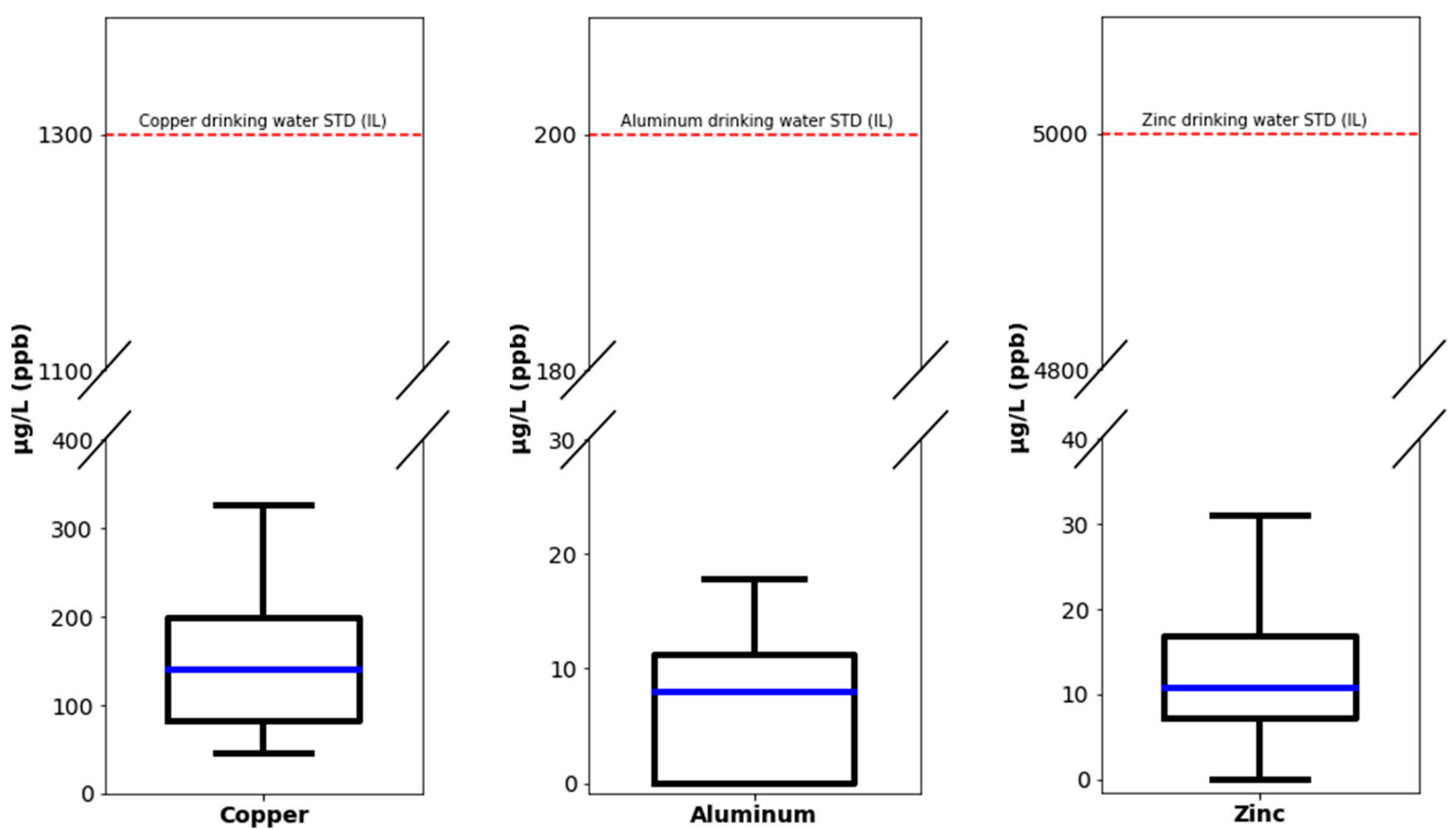

Figure 4. Levels of copper, aluminum, and zinc with comparison to drinking water standards. Note the break in the $Y$-axis scale. Blue line, median value; bottom and top frames, 25th (Q1) percentile and 75th (Q3) percentile, with the interquartile range (IQR) (the box) between them; bottom and top whiskers, Q1 $-1.5 \times$ IQR and Q3 $+1.5 \times$ IQR; dashed red line, minimal drinking water standard (between WHO and IL)(IL specified on Fig) for the specific metal. 
Copper $(\mathrm{Cu})$ was detected in all dew water samples (median value of $140.5 \mu \mathrm{g} / \mathrm{L}$ ). Its main sources in the atmosphere are metal production, industrial combustion of lubricants, coal combustion, and vehicular road dust originating from abrasion of vehicle parts [28,29]. Thus, copper concentration in the atmosphere is expected to be higher in urban areas than in rural ones. Other studies have also found that copper concentrations in dew water are lower than the drinking water standards by at least an order of magnitude. For example, dew water studies in an urban area near Paris, France [30], and an urban, semiarid area in Chile [31] found $15 \mu \mathrm{g} / \mathrm{L}$ and $38.5 \mu \mathrm{g} / \mathrm{L}$ copper (median values), respectively.

Nickel was the only analyzed metal that exceeded the drinking water standard in some analyses (Figure 5). It exceeded the IL drinking water standards seven times $(n=64)$ with a maximum value of $677 \mu \mathrm{g} / \mathrm{L}$, median value below the LOQ $(5 \mu \mathrm{g} / \mathrm{L})$, and a significant standard deviation of $101.05 \mu \mathrm{g} / \mathrm{L}$. Note that the nickel concentration exceeded the LOQ value 23 times, while 6 out of 7 results that exceeded the drinking water threshold were sampled in July 2019. Nickel has an important function in enzyme activity. However, in large quantities-more than about $0.8 \mathrm{mg} /$ day for adults-it can critically damage human health. It may cause lung cancer, erode the intestines, and more [32]. It is therefore important to monitor the quantities of nickel in dew water. Nickel is mostly derived from fuel oil combustion [26] and, therefore, apparently originated from vehicle emissions from the nearby traffic. Another potential source of nickel is sea water, despite a relatively low concentration $\left(4.8 \times 10^{-4} \mathrm{mg} / \mathrm{L}\right)$ [33]. To the best of our knowledge, this is the first report on nickel concentrations in dew water. Because it exceeded the drinking water standards in a few instances, further studies should monitor its presence.

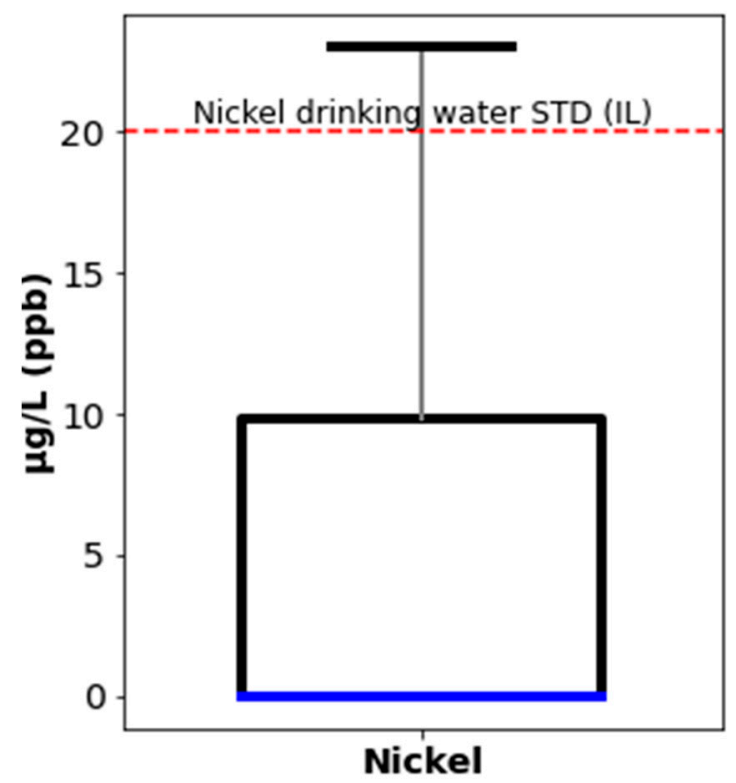

Figure 5. Nickel levels with comparison to drinking water standards. Blue line, median value; bottom and top frames, 25th (Q1) percentile and 75th (Q3) percentile, with the interquartile range (IQR) (the box) between them; bottom and top whiskers, Q1 - 1.5 $\times$ IQR and Q3 + 1.5 $\times$ IQR; dashed red line, minimal drinking water standard (between WHO and IL) (IL on Fig) for nickel.

We also detected low concentrations of calcium $\left(\mathrm{Ca}^{2+}\right)$, magnesium $\left(\mathrm{Mg}^{2+}\right)$, sodium $\left(\mathrm{Na}^{+}\right)$, and potassium $\left(\mathrm{K}^{+}\right)$ions, which are considered to be major ions in water geochemistry (Figure 6). These metals ions do not have either WHO or IL drinking water thresholds. It should be noted that $\mathrm{Mg}^{2+}$ deficiency (median value $35.5 \mu \mathrm{g} / \mathrm{L}, \mathrm{SD}=50.6$ ) and $\mathrm{Ca}^{2+}$ deficiency (median value $176 \mu \mathrm{g} / \mathrm{L}$, $\mathrm{SD}=446$ ) in drinking water can cause various health problems, such as tooth loss, rickets, and cardiac infarction [32]. Therefore, the dew water should be supplemented with these essential minerals to a concentration of $25-50 \mathrm{mg} / \mathrm{L}$ [34], as recommended for desalinated water. 

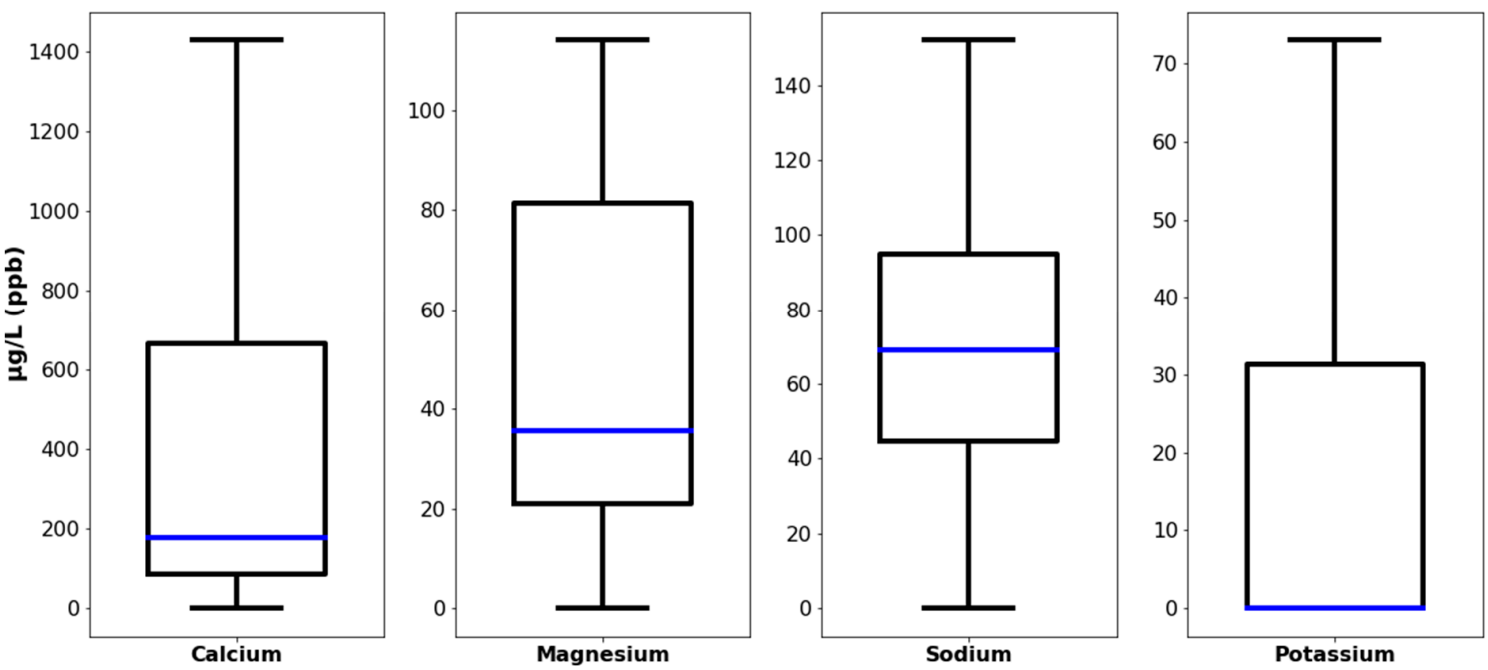

Figure 6. Levels of $\mathrm{Ca}^{2+}, \mathrm{Mg}^{2+}, \mathrm{Na}^{+}$, and $\mathrm{K}^{+}$in dew water. Blue line, median value; the bottom and and top frames are the $25^{\text {th }}(\mathrm{Q} 1)$ percentile and $75^{\text {th }}(\mathrm{Q} 3)$ percentile, with the interquartile range (IQR) (the box) between them; bottom and top whiskers are defined as Q1 - 1.5 $\times$ IQR and Q3 + 1.5 $\times$ IQR.

Other metals were found in negligible quantities (a few micrograms per liter, below their LOQ) and did not exceed the drinking water standards. There is no minimum required concentration for these substances in drinking water (Table 1). However, it is important to keep track of them as they can warn of potential contamination, possibly from the AWG (e.g., iron).

The metals in the water originate from both local emissions (transportation, industry, and marine aerosols) and long-range atmospheric transport. Nevertheless, the overall levels of the metals in the produced dew water were much lower than the WHO and IL drinking water standards.

\subsubsection{Inorganic Ions}

The concentrations of the seven ions that were analyzed in the dew water were far below the WHO or IL drinking water standards (Table 1). $\mathrm{NO}_{3}{ }^{-}, \mathrm{SO}_{4}{ }^{2-}$, and chloride $\left(\mathrm{Cl}^{-}\right)$values were lower by two orders of magnitude than the drinking water standards, and nitrite $\left(\mathrm{NO}_{2}{ }^{-}\right)$values by one order of magnitude.

\subsubsection{Ammonium}

Since $\mathrm{NH}_{4}{ }^{+}$in the drinking water does not have any immediate relevance to health, there is no standard value in the WHO or IL guidelines. Nevertheless, a threshold odor concentration for $\mathrm{NH}_{4}{ }^{+}$of about $1500 \mu \mathrm{g} / \mathrm{L}$ has been reported, and a value of $35,000 \mu \mathrm{g} / \mathrm{L}$ has been set for the taste threshold [24]. $\mathrm{NH}_{4}{ }^{+}$in dew water exceeded the LOQ value $(100 \mu \mathrm{g} / \mathrm{L}) 57$ out of 64 times $(89 \%)$, with a median value of $757.53 \mu \mathrm{g} / \mathrm{L}(\mathrm{SD}=537.85)$. Therefore, $\mathrm{NH}_{4}{ }^{+}$concentration does not affect the quality of the water produced by the AWG.

\subsubsection{VOCs and SVOCs}

To the best of our knowledge, this is the first study of VOCs and SVOCs in dew water. The SVOC analysis was performed on 25 of the 64 water samples. Of all 32 analyzed compounds (Appendix A), only fluoranthene $\left(\mathrm{C}_{16} \mathrm{H}_{10}\right)$ and benzo[a]pyrene $\left(\mathrm{C}_{20} \mathrm{H}_{12}\right)$, which belong to the PAH group, exceeded the LOQ value in two dew samplings. Fluoranthene was found twice in the dew at $0.03 \mu \mathrm{g} / \mathrm{L}$, but it does not have a standard value in the WHO or IL drinking water guidelines. The values of dew samples that exceeded the LOQ for benzo[a]pyrene were 0.67 and $0.19 \mu \mathrm{g} / \mathrm{L}$, and the IL drinking water standard is $0.5 \mu \mathrm{g} / \mathrm{L}$, thus, only one sample exceeded the IL (and WHO) drinking water standards.

Benzo[a]pyrene is formed when a material such as gasoline or wood burns incompletely and the residue sticks to the air particles. Its origin can be vehicle fuel emissions, especially from diesel 
engines [35], or the industry around the Tel Aviv metropolitan area [36]. As a byproduct of incomplete combustion and pyrolysis of carbon-containing fuels, benzo[a]pyrene has been identified in ambient air, surface water, and drinking water. Exposure to benzo[a]pyrene is associated with adverse birth outcomes and lung cancer [37], and, therefore, its presence in dew water should be further monitored to examine whether its rise above the drinking water standards was indeed a one-time event. Both fluoranthene and benzo[a]pyrene exceeded the LOQ values in the same dew samples, from 8 March 2020. However, climate conditions and air data did not show any extreme values on that day. In conclusion, except for this exceptional case, the dew water complied with the drinking water guidelines for the analyzed SVOC substances.

VOC analysis was performed on 25 of the 64 water samples. Of all 27 analyzed compounds (Appendix B), only chloroform $\left(\mathrm{CHCl}_{3}\right)$ exceeded the $\mathrm{LOQ}$, once, with a value of $0.16 \mu \mathrm{g} / \mathrm{L}$ on March 2020. Nevertheless, neither IL $(80 \mu \mathrm{g} / \mathrm{L})$ nor WHO $(300 \mu \mathrm{g} / \mathrm{L})$ drinking water standards were exceeded. Anthropogenic sources of chloroform in the atmosphere could derive from plastics production, water-treatment plants, pesticide production, or hazardous substance-treatment facilities. Natural sources of chloroform are volcanic eruptions and emissions from marine algae and fungi [38]. Because the sampling site was in an urban area, the chloroform is likely to have originated from anthropogenic sources.

\subsection{5. $\mathrm{pH}$ and Neutralization Factor}

The $\mathrm{pH}$ values of the dew samples $(\mathrm{n}=47)$ ranged from 6.5 to 7.9 , with a median value of 7.3. While the WHO does not have a $\mathrm{pH}$ standard, the IL standard ranges between 6.5 and 9.5. $\mathrm{pH}$ values of dew water vary significantly across sites, ranging between 4.0 and 7.9, with wide daily variations due to the variable sources of ions. However, in most studies, the mean $\mathrm{pH}$ values usually remain fairly close to neutral [16]. The average $\mathrm{pH}$ of dew in the Israeli Negev desert is 7.4 [39], which is almost the same as the dew water $\mathrm{pH}$ found in this study.

The basic components $\left(\mathrm{Mg}^{2+}, \mathrm{Ca}^{2+}, \mathrm{NH}_{4}{ }^{+}\right.$, and $\left.\mathrm{K}^{+}\right)$react with the acidic elements $\left(\mathrm{NO}_{3}{ }^{-}\right.$ and $\mathrm{SO}_{4}{ }^{2-}$ ) in dew water. During these reactions, acidity is lowered, and water $\mathrm{pH}$ can become neutral. To determine the role of base components in the neutralization of nitric and sulfuric acids, a neutralization factor (NF) can be calculated according to the formula [16,40]:

$$
\mathrm{NF}_{\mathrm{X}}=\frac{[\mathrm{X}]}{\left[\mathrm{NO}_{3}^{-}\right]+\left[\mathrm{SO}_{4}^{2-}\right]}
$$

where $[X]$ is the concentration of the elements responsible for neutralization (all concentrations are in units of $\mu \mathrm{Eq} / \mathrm{L})$. The strength of neutralization decreases along the order $\mathrm{NH}_{4}{ }^{+}(3.95)>\mathrm{Ca}^{2+}(1.35)>$ $\mathrm{Mg}^{2+}(0.33)>\mathrm{K}^{+}(0.0)$. The high concentration of $\mathrm{NH} 4+$ compared to the other elements in dew water implies that it is the strongest neutralization factor, followed by $\mathrm{Ca}^{2+}, \mathrm{Mg}^{2+}$, and $\mathrm{K}^{+}$. Usually, $\mathrm{NH}_{4}{ }^{+}$or $\mathrm{Ca}^{2+}$ are considered the most dominant neutralizing elements in dew water. Similar to our results, the neutralization effect of $\mathrm{K}^{+}$is nearly negligible in all studies $[19,30,41]$.

\subsection{Chemical Composition of Dew Water Produced during the Day and Night}

Atmospheric characteristics can vary between day and night. During the day, the ambient temperature is higher, and the relative humidity is usually lower than at night because warmer air has the potential to hold more water vapor. During the daytime, more anthropogenic pollutants associated with industrial activity and traffic are emitted than at night. In addition, the daytime is characterized by photochemical reactions [42,43]. This is the first examination of the effect of time (day vs night) on the chemical composition of water produced by the AWG. The samples were divided into two groups: daytime—dew samples produced between 06:00 and 17:59 $(n=37)$ and night-time-dew samples produced between 18:00 and 05:59 $(\mathrm{n}=27)$ (Table 2). The hours are in local time (IST). The statistical 
analysis was performed with a two-tailed Mann-Whitney $U$ test [44] (the nonparametric version of Student's t-test), because the data were comprised of independent samples.

Table 2. Concentrations of the various chemical substances in dew water, divided into daytime and night-time samples, and Mann-Whitney $U$ test results.

\begin{tabular}{|c|c|c|c|}
\hline Parameter & $\begin{array}{l}\text { Day Median } \\
(\mu \mathrm{g} / \mathrm{L} \pm \mathrm{SD})\end{array}$ & $\begin{array}{c}\text { Night Median } \\
(\mu \mathrm{g} / \mathrm{L} \pm \mathrm{SD})\end{array}$ & Mann-Whitney U Test \\
\hline \multicolumn{4}{|c|}{ Metals } \\
\hline Copper & $139.0 \pm 72.7$ & $146.0 \pm 145.5$ & $\begin{array}{l}\mathrm{U}=457.0 \\
\mathrm{P}=0.284\end{array}$ \\
\hline Aluminum & $8.4 \pm 7.7$ & $7.1 \pm 6.8$ & $\begin{array}{l}\mathrm{U}=472.5 \\
\mathrm{P}=0.357\end{array}$ \\
\hline Zinc & $9.4 \pm 37.4$ & $11.0 \pm 8.3$ & $\begin{array}{l}\mathrm{U}=388.0 \\
\mathrm{P}=0.065\end{array}$ \\
\hline Nickel & $<\mathrm{LOQ} \pm 126.4$ & $<\mathrm{LOQ} \pm 46.5$ & $\begin{array}{l}\mathrm{U}=417.0 \\
\mathrm{P}=0.097\end{array}$ \\
\hline Calcium & $279.0 \pm 501.4$ & $111.0 \pm 287.6$ & $\begin{array}{l}\mathrm{U}=307.0 \\
\mathrm{P}=0.004\end{array}$ \\
\hline Magnesium & $52.0 \pm 50.2$ & $32.0 \pm 51.5$ & $\begin{array}{l}\mathrm{U}=434.5 \\
\mathrm{P}=0.189\end{array}$ \\
\hline Sodium & $75.0 \pm 447.7$ & $69.0 \pm 72.4$ & $\begin{array}{l}\mathrm{U}=476.5 \\
\mathrm{P}=0.379\end{array}$ \\
\hline Potassium & $<\mathrm{LOQ} \pm 27.8$ & $<\mathrm{LOQ} \pm 23.7$ & $\begin{array}{l}\mathrm{U}=470.0 \\
\mathrm{P}=0.328\end{array}$ \\
\hline \multicolumn{4}{|c|}{ Ions } \\
\hline Nitrate & $200.0 \pm 321.3$ & $232.0 \pm 170.0$ & $\begin{array}{l}\mathrm{U}=442.5 \\
\mathrm{P}=0.220\end{array}$ \\
\hline Nitrite & $<\mathrm{LOQ} \pm 236.8$ & $<\mathrm{LOQ} \pm 129.9$ & $\begin{array}{l}\mathrm{U}=435.5 \\
\mathrm{P}=0.168\end{array}$ \\
\hline Sulfate & $270.0 \pm 391.9$ & $220.0 \pm 349.4$ & $\begin{array}{l}\mathrm{U}=427.0 \\
\mathrm{P}=0.163\end{array}$ \\
\hline Chloride & $120.0 \pm 257.7$ & $120.0 \pm 129.4$ & $\begin{array}{l}\mathrm{U}=466.0 \\
\mathrm{P}=0.324\end{array}$ \\
\hline \multicolumn{4}{|c|}{ Other } \\
\hline Ammonium & $780.0(\mathrm{n}=32) \pm 602$ & $590.0(n=25) \pm 431.1$ & $\begin{array}{l}\mathrm{U}=456.5 \\
\mathrm{P}=0.281\end{array}$ \\
\hline
\end{tabular}

Despite the known different atmospheric characteristics between day and night, we did not find any significant difference between the time (day/night) of dew water production and its chemical characteristics, except for $\mathrm{Ca}^{2+}$. These results indicate that the AWG can produce potable water $24 \mathrm{~h}$ a day.

\section{Conclusions}

Our comprehensive analyses suggest that the production of dew water by an AWG in a large urban area can provide safe drinking water, during the day and at night, throughout the year. There was high variability in the concentrations of most substances between the water samples. Special attention and monitoring efforts should be payed to nickel and benzo[a]pyrene that were the only compounds that exceeded the drinking water standards. We demonstrate that the atmospheric water produced by AWGs can be a potential source of potable water, which may assist in dealing with the severe water scarcity existing across the globe, and specifically in remote and inland regions. The chemistry of the 
dew water showed large variability between days and seasons. Therefore, future research efforts should examine the influence of anthropogenic air pollution, meteorological conditions, and atmospheric processes on the chemical characteristics of the produced dew water.

Author Contributions: Conceptualization, D.A. and S.R.; methodology, D.A., S.R. and I.G.; software, O.I. and Y.A.; validation, I.G. and S.R.; formal analysis, I.G., O.I., S.R. and Y.A.; investigation, O.I.; resources, D.A. and R.S.; data curation, O.I.; writing-O.I. and D.A.; writing-review and editing, O.I., D.A., I.G., R.S., Y.A. and S.R.; visualization, O.I.; supervision, D.A. and S.R.; project administration, D.A.; funding acquisition, D.A. and S.R All authors have read and agreed to the published version of the manuscript.

Funding: This research was funded by an [Internal Foundation of the Water Research Center at TAU-“The Moshe Mirilashvili foundation".

Acknowledgments: Many thanks to the engineers at Watergen Ltd. who built the field AWG generator, and to our laboratory colleagues at the Water Research Center, Tel Aviv University—Gefen Ronen-Eliraz, Aviv Kaplan, and Eli Margalit-for their advice and assistance.

Conflicts of Interest: The authors declare that they have no known competing financial interests or personal relationships that could appear to have influenced the work reported in this paper.

\section{Appendix A. Analysis of Semi-Volatile Organic Compounds}

Table A1. Polycyclic aromatic hydrocarbon compounds and their corresponding retention time, selected ion monitoring mode (SIM), qualifiers, and LOQ.

\begin{tabular}{ccccccc}
\hline Description & CAS \# & $\begin{array}{c}\text { Retention } \\
\text { Time (min) }\end{array}$ & SIM & $\begin{array}{c}\text { Qualifier 1/ } \\
\text { Qualifier } 2\end{array}$ & $\begin{array}{c}\text { LOQ } \\
(\mu \mathrm{g} / \mathrm{L})\end{array}$ \\
\hline 1,2,3-Trimethylbenzene & $526-73-8$ & 5.81 & 105 & 120 & 119 & 0.01 \\
\hline Naphthalene & $91-20-3$ & 7.59 & 128 & 127 & 126 & 0.01 \\
\hline 2-Methylnaphthalene & $91-57-6$ & 8.67 & 142 & 141 & 139 & 0.01 \\
\hline Acenaphthylene & $208-96-8$ & 10.09 & 152 & 151 & 150 & 0.01 \\
\hline Fluorene & $86-73-7$ & 11.19 & 166 & 165 & 163 & 0.01 \\
\hline Phenanthrene & $85-01-8$ & 12.72 & 178 & 177 & 176 & 0.025 \\
\hline Anthracene & $120-12-7$ & 12.8 & 178 & 177 & 176 & 0.01 \\
\hline Fluoranthene & $206-44-0$ & 14.63 & 202 & 200 & 201 & 0.01 \\
\hline Pyrene & $129-00-0$ & 14.98 & 202 & 200 & 201 & 0.01 \\
\hline Benz[a]anthracene & $56-55-3$ & 16.91 & 228 & 226 & 227 & 0.01 \\
\hline Chrysene & $218-01-9$ & 16.96 & 228 & 226 & 227 & 0.01 \\
\hline Benzo[b]fluoranthene & $205-99-2$ & 18.79 & 252 & 250 & 251 & 0.01 \\
\hline Benzo[k]fluoranthene & $207-08-9$ & 18.84 & 252 & 250 & 251 & 0.01 \\
\hline Benzo[a]pyrene & $50-32-8$ & 19.33 & 252 & 250 & 251 & 0.01 \\
\hline Indeno [1,2,3-cd]pyrene & $193-39-5$ & 21.0 & 276 & 274 & & 0.025 \\
\hline Dibenz[a,h]anthracene & $53-70-3$ & 21.04 & 278 & 139 & & 0.025 \\
\hline Benzo[g,h,i]perylene & $191-24-2$ & 21.38 & 276 & 274 & & 0.025 \\
\hline & & & & & & \\
\hline & & & 250 & \\
\hline
\end{tabular}


Table A2. Polychlorinated biphenyl compounds and their corresponding retention time, selected ion monitoring mode (SIM), qualifiers, and LOQ.

\begin{tabular}{|c|c|c|c|c|c|c|}
\hline \multirow{2}{*}{$\begin{array}{c}\text { Description } \\
\text { 2-Chlorobiphenyl } \\
\text { (PCB 1) }\end{array}$} & \multirow{2}{*}{$\begin{array}{c}\text { CAS \# } \\
2051-60-7\end{array}$} & \multirow{2}{*}{$\begin{array}{c}\begin{array}{c}\text { Retention } \\
\text { Time (min) }\end{array} \\
10.456\end{array}$} & \multirow{2}{*}{$\begin{array}{l}\text { SIM } \\
188.0\end{array}$} & \multicolumn{2}{|c|}{$\begin{array}{l}\text { Qualifier 1/ } \\
\text { Qualifier } 2\end{array}$} & \multirow{2}{*}{$\begin{array}{c}\begin{array}{c}\text { LOQ } \\
(\mu \mathrm{g} / \mathrm{L})\end{array} \\
0.01\end{array}$} \\
\hline & & & & 190.1 & 152 & \\
\hline $\begin{array}{l}\text { 4-Chlorobiphenyl } \\
\text { (PCB 3) }\end{array}$ & $2051-62-9$ & 11.133 & 188.0 & 190.1 & 152 & 0.01 \\
\hline $\begin{array}{l}\text { 2,4'-Dichlorobiphenyl } \\
\text { (PCB 8) }\end{array}$ & $34883-43-7$ & 12.055 & 222.1 & 224 & 152 & 0.01 \\
\hline $\begin{array}{l}\text { 2,2',5-Trichlorobiphenyl } \\
\text { (PCB 18) }\end{array}$ & $37680-65-2$ & 12.647 & 255.9 & 257.9 & 186 & 0.01 \\
\hline $\begin{array}{l}\text { 2,4,4'-Trichlorobiphenyl } \\
\text { (PCB 28) }\end{array}$ & $7012-37-5$ & 13.315 & 255.9 & 257.9 & 186 & 0.01 \\
\hline $\begin{array}{c}2,2^{\prime}, 5,5^{\prime} \text {-Tetrachlorobiphenyl } \\
\text { (PCB 52) }\end{array}$ & $35693-99-3$ & 13.768 & 291.9 & 289.9 & 219.9 & 0.01 \\
\hline $\begin{array}{c}2,2^{\prime}, 3,5^{\prime}-\text { Tetrachlorobiphenyl } \\
\text { (PCB 44) }\end{array}$ & 41464-39-5 & 14.028 & 291.9 & 289.9 & 219.9 & 0.01 \\
\hline $\begin{array}{c}2,3^{\prime}, 4^{\prime}, 5-\text { Tetrachlorobiphenyl } \\
\text { (PCB 70) }\end{array}$ & $32598-11-1$ & 14.563 & 291.9 & 289.9 & 219.9 & 0.01 \\
\hline $\begin{array}{l}\text { 2,3,3', } 4^{\prime}, 6 \text {-Pentachlorobiphenyl } \\
\text { (PCB 110) }\end{array}$ & $38380-03-9$ & 15.341 & 325.9 & 323.9 & 327.9 & 0.01 \\
\hline $\begin{array}{c}2,2^{\prime}, 3,4^{\prime}, 5^{\prime}, 6-\text {-Hexachlorobiphenyl } \\
\text { (PCB 149) }\end{array}$ & $38380-04-0$ & 15.633 & 359.9 & 361.8 & 357.8 & 0.01 \\
\hline $\begin{array}{l}2,3^{\prime}, 4,4^{\prime}, 5 \text {-Pentachlorobiphenyl } \\
\text { (PCB 118) }\end{array}$ & $31508-00-6$ & 15.685 & 325.9 & 323.9 & 327.9 & 0.01 \\
\hline $\begin{array}{c}2,2^{\prime}, 4,4^{\prime}, 5,5^{\prime} \text {-Hexachlorobiphenyl } \\
\text { (PCB 153) }\end{array}$ & $35065-27-1$ & 15.947 & 359.9 & 361.8 & 357.8 & 0.01 \\
\hline $\begin{array}{c}2,2^{\prime}, 3,4,4^{\prime}, 5^{\prime}-\text { Hexachlorobiphenyl } \\
\text { (PCB 138) }\end{array}$ & $35065-28-2$ & 16.28 & 359.9 & 361.8 & 357.8 & 0.01 \\
\hline $\begin{array}{c}2,2^{\prime}, 3,4,4^{\prime}, 5,5^{\prime}- \\
\text { Heptachlorobiphenyl } \\
\text { (PCB 180) }\end{array}$ & $35065-29-3$ & 17.093 & 395.8 & 393.8 & 397.8 & 0.01 \\
\hline
\end{tabular}

Table A3. Internal standards used for semi-volatile organic compound analysis.

\begin{tabular}{cccc}
\hline Description & CAS \# & Retention Time (min) & SIM \\
\hline Acenaphthene-d10 & $15067-26-2$ & 10.31 & 164.2 \\
\hline Phenanthrene-d10 & $1517-22-2$ & 12.68 & 188.2 \\
\hline Chrysene-d12 & $1719-03-5$ & 16.92 & 240.2 \\
\hline \multicolumn{5}{c}{ SIM, selected ion monitoring mode. }
\end{tabular}




\section{Appendix B. Analysis of Volatile Organic Compounds}

Table A4. Volatile organic compounds and their corresponding retention time, selected ion monitoring mode (SIM), qualifiers, and LOQ.

\begin{tabular}{|c|c|c|c|c|c|c|}
\hline \multirow{2}{*}{$\begin{array}{c}\text { Description } \\
\text { 1,2-Dichloroethane }\end{array}$} & \multirow{2}{*}{$\begin{array}{c}\text { CAS \# } \\
107-06-2\end{array}$} & \multirow{2}{*}{$\begin{array}{c}\begin{array}{c}\text { Retention } \\
\text { Time (min) }\end{array} \\
6.80 \\
\end{array}$} & \multirow{2}{*}{$\begin{array}{c}\text { SIM } \\
96\end{array}$} & \multicolumn{2}{|c|}{$\begin{array}{l}\text { Qualifier 1/ } \\
\text { Qualifier } 2\end{array}$} & \multirow{2}{*}{$\begin{array}{c}\mathrm{LOQ} \\
(\mu \mathrm{g} / \mathrm{L})\end{array}$} \\
\hline & & & & 98 & 61 & \\
\hline $\begin{array}{l}\text { Methylene chloride } \\
\text { (dichloromethane) }\end{array}$ & $75-09-2$ & 7.64 & 84 & 86 & 49 & 0.2 \\
\hline cis-1,2-Dichloroethene & $156-59-2$ & 8.03 & 96 & 98 & 61 & 0.2 \\
\hline trans-1,2-Dichloroethene & $156-60-5$ & 9.53 & 96 & 98 & 61 & 0.2 \\
\hline Chloroform & $67-66-3$ & 10.00 & 83 & 85 & 87 & 0.1 \\
\hline 1,1,1-Trichloroethane & $71-55-6$ & 10.25 & 97 & 99 & 117 & 0.2 \\
\hline Carbon tetrachloride & $56-23-5$ & 10.47 & 117 & 119 & 121 & 0.2 \\
\hline Benzene & $71-43-2$ & 10.77 & 78 & 77 & 52 & 0.2 \\
\hline 1,1-Dichloroethene & $75-35-4$ & 10.86 & 62 & 64 & 98 & 0.2 \\
\hline Fluorobenzene (internal standard) & $462-06-6$ & 11.18 & 96 & 70 & & 0.2 \\
\hline Trichloroethene & 79-01-6 & 11.69 & 130 & 132 & 95 & 0.2 \\
\hline 1,2-Dichloropropane & $78-87-5$ & 12.14 & 63 & 62 & & 0.2 \\
\hline Bromodichloromethane & $75-27-4$ & 12.50 & 83 & 85 & 129 & 0.1 \\
\hline Toluene & $108-88-3$ & 13.68 & 91 & 92 & & 0.2 \\
\hline 1,1,2-Trichloroethane & $79-00-5$ & 14.33 & 97 & 99 & 83 & 0.2 \\
\hline Tetrachloroethene & $127-18-4$ & 14.52 & 166 & 164 & 168 & 0.2 \\
\hline Dibromochloromethane & $124-48-1$ & 14.99 & 129 & 127 & 131 & 0.2 \\
\hline Chlorobenzene & $108-90-7$ & 16.04 & 112 & 114 & 77 & 0.1 \\
\hline Ethylbenzene & $100-41-4$ & 16.16 & 106 & 91 & & 0.1 \\
\hline m-Xylene & $108-38-3$ & 16.37 & 91 & 106 & 105 & 0.2 \\
\hline p-Xylene & $106-42-3$ & 16.37 & 91 & 106 & 105 & 0.2 \\
\hline o-Xylene & $95-47-6$ & 17.07 & 91 & 106 & 105 & 0.2 \\
\hline Styrene & $100-42-5$ & 17.10 & 104 & 105 & 78 & 0.1 \\
\hline Bromoform & $75-25-2$ & 17.46 & 173 & 171 & 175 & 0.2 \\
\hline 1,4-Dichlorobenzene & $106-46-7$ & 20.23 & 146 & 148 & 111 & 0.1 \\
\hline 1,2-Dichlorobenzene & $95-50-1$ & 20.91 & 146 & 148 & 111 & 0.1 \\
\hline 1,2,4-Trichlorobenzene & $120-82-1$ & 23.92 & 180 & 182 & 184 & 0.1 \\
\hline
\end{tabular}

\section{Appendix C. Elements in Dew Water over Time}

There was some concern about the active dew collector becoming contaminated. Comparing values of different substances over time, we found this not to be the case, thus, subsequent days were not affected by each other. 

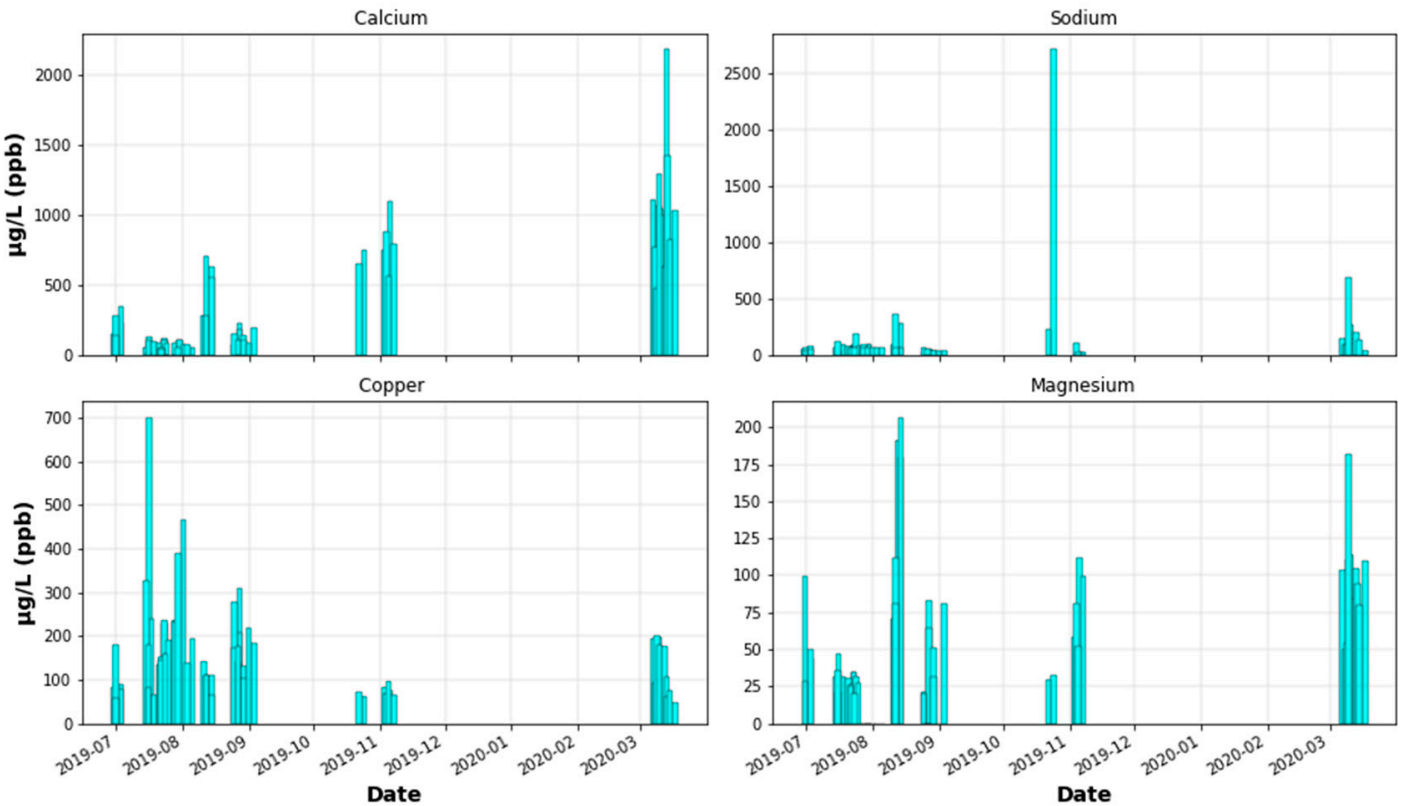

Figure A1. Calcium, copper, sodium, and magnesium concentrations in dew water over time. Each bar represents a specific dew water sample.

Appendix C.2. Ions
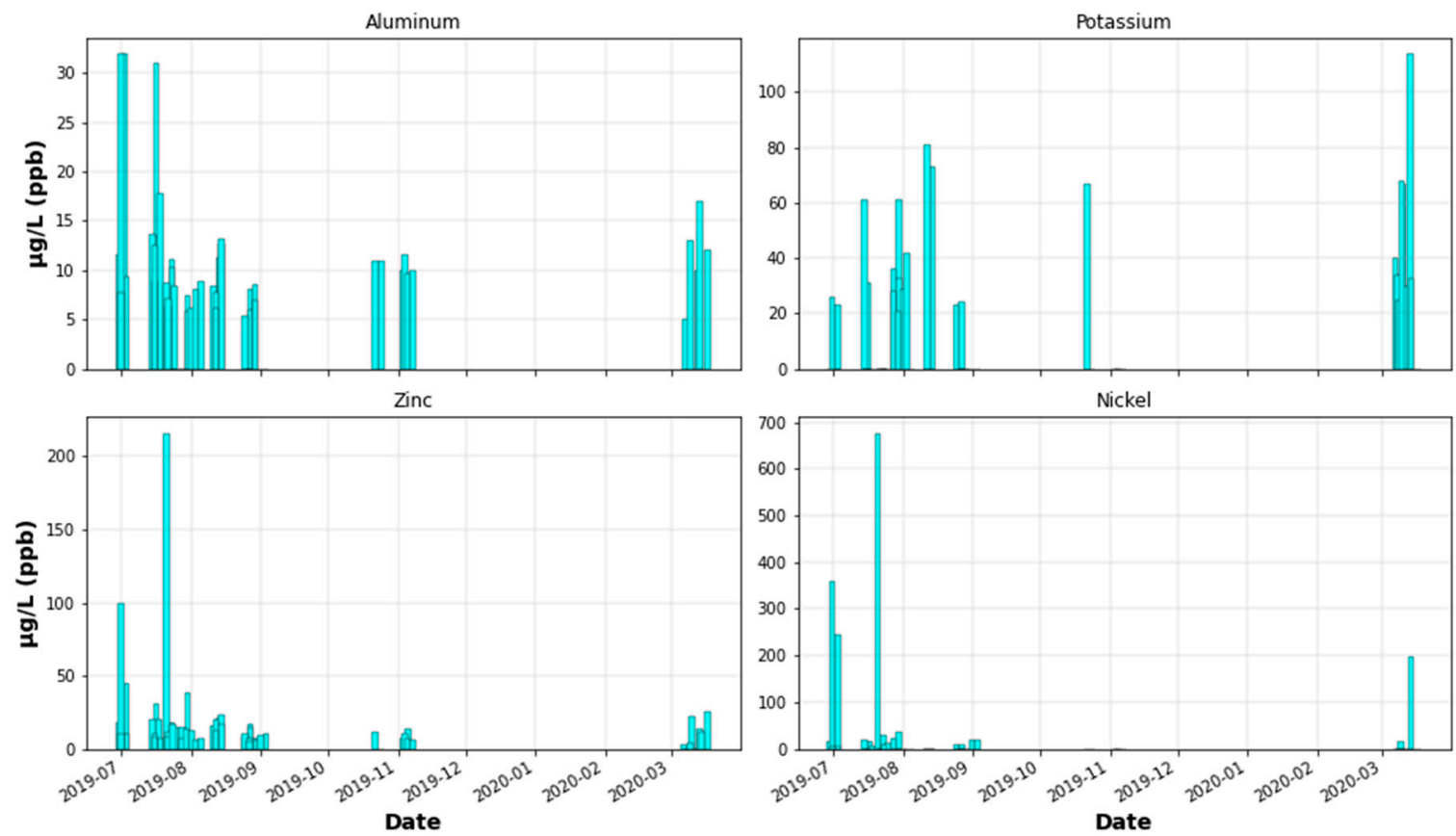

Figure A2. Aluminum, potassium, zinc and nickel concentrations in dew water over time. Each bar represents a specific dew water sample. 


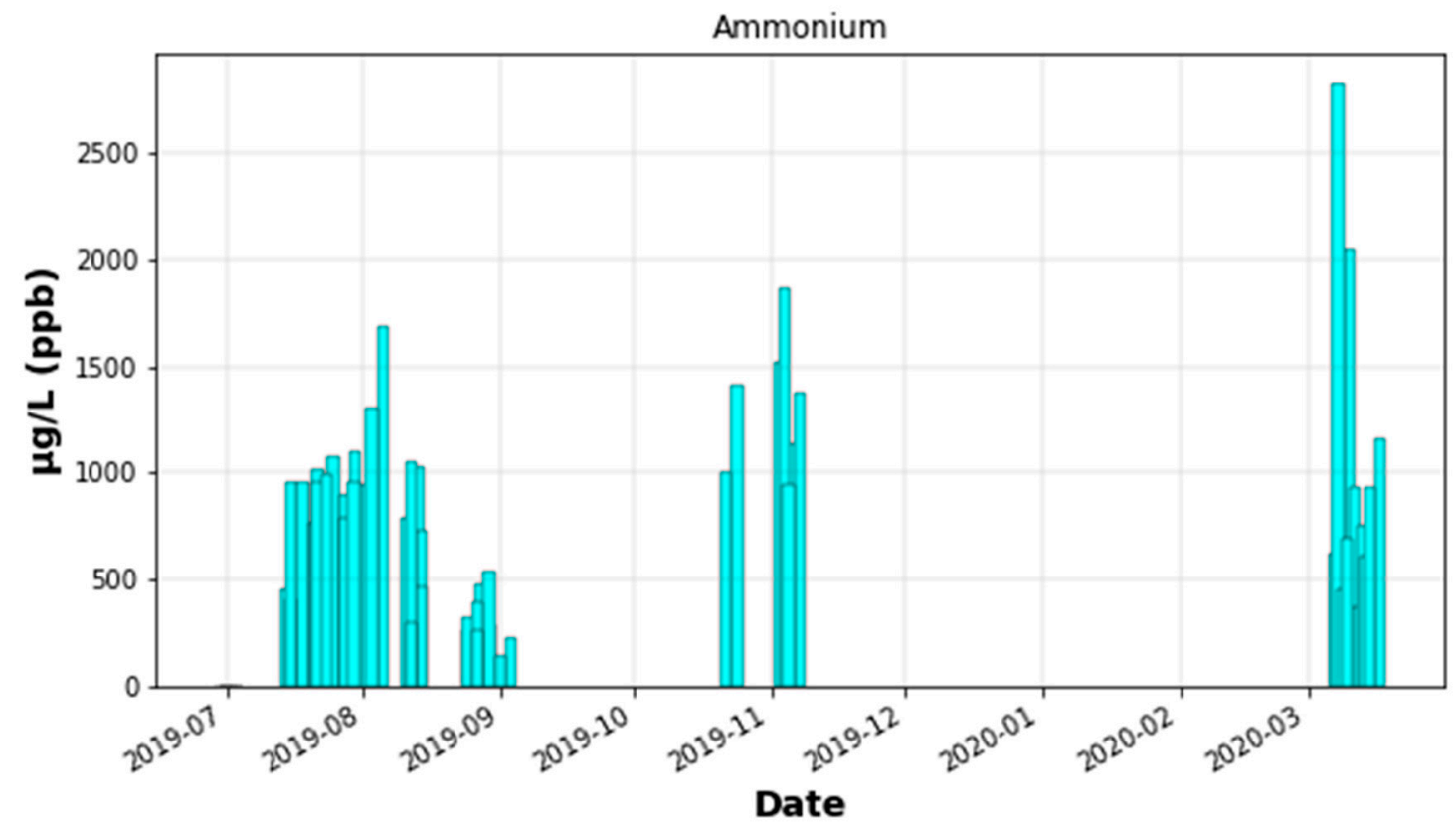

Figure A3. Ammonium concentration in dew water over time. Each bar represents a specific dew water sample.

\section{References}

1. Mekonnen, M.M.; Hoekstra, A.Y. Four billion people facing severe water scarcity. Sci. Adv. 2016, 2, e1500323. [CrossRef] [PubMed]

2. World Economic Forum. The Global Risks Report; World Economic Forum: Geneva, Switzerland, 2019.

3. UNESCO. Leaving No One Behind; UNSECO: Paris, France, 2019.

4. Semiat, R. Energy issues in desalination processes. Environ. Sci. Technol. 2008, 42, 8193-8201. [CrossRef] [PubMed]

5. $\quad$ Li, R.; Shi, Y.; Alsaedi, M.; Wu, M.; Shi, L.; Wang, P. Hybrid Hydrogel with High Water Vapor Harvesting Capacity for Deployable Solar-Driven Atmospheric Water Generator. Environ. Sci. Technol. 2018, 52, 11367-11377. [CrossRef] [PubMed]

6. Tomaszkiewicz, M.; Abou Najm, M.; Beysens, D.; Alameddine, I.; El-Fadel, M. Dew as a sustainable non-conventional water resource: A critical review. Environ. Rev. 2015, 23, 425-442. [CrossRef]

7. Khalil, B.; Adamowski, J.; Shabbir, A.; Jang, C.; Rojas, M.; Reilly, K.; Ozga-Zielinski, B. A review: Dew water collection from radiative passive collectors to recent developments of active collectors. Sustain. Water Resour. Manag. 2016, 2, 71-86. [CrossRef]

8. Dong, M.; Zhang, Z.; Shi, Y.; Zhao, X.; Fan, S.; Chen, Z. Fundamental Limits of the Dew-Harvesting Technology. Nanoscale Microscale Thermophys. Eng. 2020, 24, 43-52. [CrossRef]

9. Tripathi, A.; Tushar, S.; Pal, S.; Lodh, S.; Tiwari, S.; Desai, R.S. Atmospheric Water Generator. Int. J. Enhanced Res. Sci. 2016, 5, 69-72.

10. Peters, G.M.; Blackburn, N.J.; Armedion, M. Environmental assessment of air to water machines-Triangulation to manage scope uncertainty. Int. J. Life Cycle Assess. 2013, 18, 1149-1157. [CrossRef]

11. GEN-L-Watergen. Available online: https://www.watergen.com/product/gen-1/ (accessed on 7 June 2020).

12. EcoloBlue. Available online: http://www.ecoloblueblog.com/ (accessed on 27 May 2020).

13. Skywater. Available online: https://www.skywater.com/ (accessed on 4 June 2020).

14. Watergen. Available online: https://www.watergen.com/ (accessed on 7 June 2020).

15. Gido, B.; Friedler, E.; Broday, D.M. Liquid-Desiccant Vapor Separation Reduces the Energy Requirements of Atmospheric Moisture Harvesting. Environ. Sci. Technol. 2016. [CrossRef] 
16. Beysens, D. Dew Water; River Publishers: Gistrup, Denmark, 2018; ISBN 9788793609471.

17. Singh, S.P.; Khare, P.; Kumari, K.M.; Srivastava, S.S. Chemical characterization of dew at a regional representative site of North-Central India. Atmos. Res. 2006, 80, 239-249. [CrossRef]

18. Blaś, M.; Sobik, M.; Polkowska, Z.; Cichala-Kamrowska, K.; Namieśnik, J. Water and chemical properties of hydrometeors over Central European mountains. Pure Appl. Geophys. 2012, 169, 1067-1081. [CrossRef]

19. Lekouch, I.; Muselli, M.; Kabbachi, B.; Ouazzani, J.; Melnytchouk-Milimouk, I.; Beysens, D. Dew, fog, and rain as supplementary sources of water in south-western Morocco. Energy 2011, 36, 2257-2265. [CrossRef]

20. Acker, K.; Beysens, D.; Möller, D. Nitrite in dew, fog, cloud and rain water: An indicator for heterogeneous processes on surfaces. Atmos. Res. 2008, 87, 200-212. [CrossRef]

21. Muskała, P.; Sobik, M.; Błaś, M.; Polkowska, Ż.; Bokwa, A. Pollutant deposition via dew in urban and rural environment, Cracow, Poland. Atmos. Res. 2015, 151, 110-119. [CrossRef]

22. Beysens, D.; Milimouk, I.; Nikolayev, V.; Muselli, M.; Marcillat, J. Using radiative cooling to condense atmospheric vapor: A study to improve water yield. J. Hydrol. 2003, 276, 1-11. [CrossRef]

23. Xu, Y.; Zhu, H.; Tang, J.; Lin, Y. Chemical Compositions of Dew and Scavenging of Particles in Changchun, China. Adv. Meteorol. 2015, 1-11. [CrossRef]

24. WHO. A Global Overview of National Regulations and Standards for Drinking-Water Quality; WHO: Geneva, Switzerland, 2018.

25. Israeli Ministry of Health Public Health Regulations. The Sanitary Quality of Drinking Water and Drinking Water Facilities (in Hebrew). Available online: https://www.health.gov.il/LegislationLibrary/Briut47.pdf (accessed on 8 June 2020).

26. Heo, J.; Wu, B.; Abdeen, Z.; Qasrawi, R.; Sarnat, J.A.; Sharf, G.; Shpund, K.; Schauer, J.J. Source apportionments of ambient fine particulate matter in Israeli, Jordanian, and Palestinian cities. Environ. Pollut. 2017, 225, 1-11. [CrossRef]

27. Mamane, Y.; Perrino, C.; Yossef, O.; Catrambone, M. Source characterization of fine and coarse particles at the East Mediterranean coast. Atmos. Environ. 2008, 42, 6114-6130. [CrossRef]

28. Taiwo, A.M.; Harrison, R.M.; Shi, Z. A review of receptor modelling of industrially emitted particulate matter. Atmos. Environ. 2014, 97, 109-120. [CrossRef]

29. Das, R.; Khezri, B.; Srivastava, B.; Datta, S.; Sikdar, P.K.; Webster, R.D.; Wang, X. Trace element composition of PM2.5 and PM10 from kolkata-a heavily polluted indian metropolis. Atmos. Pollut. Res. 2015, 6, 742-750. [CrossRef]

30. Beysens, D.; Mongruel, A.; Acker, K. Urban dew and rain in Paris, France: Occurrence and physico-chemical characteristics. Atmos. Res. 2017, 189, 152-161. [CrossRef]

31. Carvajal, D.; Minonzio, J.G.; Casanga, E.; Muñoz, J.; Aracena, A.; Montecinos, S.; Beysens, D. Roof-integrated dew water harvesting in Combarbalá, Chile. J. Water Supply Res. Technol. AQUA 2018, 67, 357-374. [CrossRef]

32. Rosborg, I.; Kozisek, F.; Precautions, S. Drinking Water Minerals and Mineral Balance; Springer International Publishing: Cham, Switzerland, 2019; ISBN 9783030180331.

33. Wright, J.; Colling, A. THE SEAWATER SOLUTION. In Seawater: Its Composition, Properties and Behaviour; Elsevier: Amsterdam, The Netherlands, 1995; pp. 85-127.

34. WHO. Calcium and Magnesium in Drinking-Water; WHO: Geneva, Switzerland, 2009; ISBN 9789241563550.

35. Gianelle, V.; Colombi, C.; Caserini, S.; Ozgen, S.; Galante, S.; Marongiu, A.; Lanzani, G. Benzo(a)pyrene air concentrations and emission inventory in Lombardy region, Italy. Atmos. Pollut. Res. 2013, 4, 257-266. [CrossRef]

36. Zheng, M.; Fang, M. Particle-associated polycyclic aromatic hydrocarbons in the atmosphere of Hong Kong. Water. Air. Soil Pollut. 2000, 117, 175-189. [CrossRef]

37. Iris. Toxicological Review of Benzo[a]pyrene; U.S Environmental Protection Agency: Washington, DC, USA, 2017.

38. Cappelletti, M.; Frascari, D.; Zannoni, D.; Fedi, S. Microbial degradation of chloroform. Appl. Microbiol. Biotechnol. 2012, 96, 1395-1409. [CrossRef]

39. Kidron, G.J.; Starinsky, A. Chemical composition of dew and rain in an extreme desert (Negev): Cobbles serve as sink for nutrients. J. Hydrol. 2012, 420-421, 284-291. [CrossRef]

40. Das, R.; Das, S.N.; Misra, V.N. Chemical composition of rainwater and dustfall at Bhubaneswar in the east coast of India. Atmos. Environ. 2005, 39, 5908-5916. [CrossRef]

41. Hong, L.; Zhu, B.; Yu, X.; Shi, S.; Chen, K.; Xia, L. Chemical composition of dew water at a suburban site in Nanjing, China, during the 2016-2017 winter. Atmos. Environ. 2019, 226-233. [CrossRef] 
42. Szep, R.; Matyas, L.; Keresztes, R.; Ghimpusan, M. Tropospheric Ozone Concentrations-Seasonal and Daily Analysis and its Association with NO and NO2 as a Function of NO $x$ in Ciuc Depression-Romania; Revista De Chimie: Bucharest, Romania, 2016; Volume 67.

43. Roberts-Semple, D.; Song, F.; Gao, Y. Seasonal characteristics of ambient nitrogen oxides and ground-level ozone in metropolitan northeastern New Jersey. Atmos. Pollut. Res. 2012, 3, 247-257. [CrossRef]

44. McKnight, P.E.; Najab, J. Mann-Whitney U Test. In The Corsini Encyclopedia of Psychology; John Wiley \& Sons Inc.: Hoboken, NJ, USA, 2010.

Publisher's Note: MDPI stays neutral with regard to jurisdictional claims in published maps and institutional affiliations.

(C) 2020 by the authors. Licensee MDPI, Basel, Switzerland. This article is an open access article distributed under the terms and conditions of the Creative Commons Attribution (CC BY) license (http://creativecommons.org/licenses/by/4.0/). 